\title{
PENGARUH LATIHAN JOGGING TERHADAP DAYA TAHAN KARDIORESPIRASI PADA ATLET TAEKWONDO SURVIVAR 5 CLUB PALEMBANG
}

\author{
Oleh : Maya Kurnia, Hamida Anggraini \\ (Universitas Pgri Palembang ${ }^{1,2}$ ) \\ mayakurnia@univpgri-palembang.ac.id
}

\begin{abstract}
Abstrak
Tujuan dari artikel yang ingin dicapai adalah : Untuk mengetahui pengaruh latihan jogging terhadap daya tahan Kardiorespirasi pada atlet Taekwondo Suvivar 5. Dalam penelitian ini populasi keseluruhan yaitu ada 30 siswa di Taekwondo Suvivar 5 club Palembang di antara nya 15 kelas reguler (anak-anak) dan 15 kelas atlet (dewasa). Sampel penelitian adalah semua jumlah populasi yaitu sebanyak 15 orang. Teknik pengumpulan data menggunakan teknik tes dan pengukuran, teknik analisa data menggunakan ujit-t. Berdasarkan teknik analisa data dan pembahasan dapat disimpulkan bahwa " ada pengaruh latihan jogging terhadap daya tahan kardiorespirasi pada atlet taekwondo Survivar 5 Club Palembang".
\end{abstract}

Kata Kunci : Atlet, Latihan Jogging, Daya Tahan Kardiorespirasi.

\section{EFFECT OF JOGGING TRAINING ON CARDIORESPIRATION RESISTANCE ON TAEKWONDO SURVIVAR ATLET 5 CLUB PALEMBANG}

\begin{abstract}
The objectives of the research to be achieved in this study are: To study jogging research on cardiorespiration endurance in Taekwondo Suvivar 5 athletes. In this study was a study involving 30 students in Taekwondo Suvivar 5 Palembang club among 15 regular classes (children) and 15 athlete classes (adults). The study sample is all the population of 15 people. Data collection techniques using test and measurement techniques, data analysis techniques using t-test. Based on data analysis techniques and discussion it can be concluded that "there is an effect of jogging training on cardiorespiration endurance in Survivar 5 Club Palembang taekwondo athletes".

Keywords: Athletes, Jogging Exercises, Cardiorespiration Endurance.
\end{abstract}

Correspondence author: Maya Kurnia, Hamida Anggraini, Universitas PGRI Palembang, Indonesia. mayakurnia@univpgri-palembang.ac.id

\section{(c) (i) (2)}

Jurnal HalamanOlahraga Nusantara licensed under a Creative Commons Attribution-ShareAlike 4.0 International License.

\section{PENDAHULUAN}

Pembinaan olahraga di Indonesia saat ini semakin maju, hal ini tidak lepas dari peran serta masyarakat yang semakin sadar dan mengerti betapa pentingnya olahraga itu sendiri. pembinaan olahraga prestasi adalah pembinaan olahraga yang 
dilakukan dengan tujuan untuk meraih suatu prestasi olahraga, menurut (syafruddin 2013). Dalam konteks ini dapat diartikan dengan pembinaan cabangcabang olahraga yang ditujukan untuk menghadapi kompetisi/pertandingan/perlombaan mulai dari paling rendah sampai internasional. Dengan kata lain bahwa semua cabang olahraga yangg di kompetisikan / dipertandingkan secara ketat mulai dari tingkat lokal seperti Pekan Olahraga Provinsi (PORVROP), Pekan Olahraga Wilaya (PORWIL), dan lain-lain dapat disebut olahraga prestasi, Sering disebut olahraga kompetitif.

Hal ini disebabkan cabang olahraga tersebut selalu di kompetisikan pada event-event resmi. Fungsi dan peranan ilmu kepelatihan dalam pembinaan olahraga prestasi tidak perlu dipertanyakan lagi karena memang fungsinya sangat jelas dan nyata sekali. Pelatih yang tidak memahami ilmu kepelatihan tidak akan mampu meningkatkan prestasi atlet yang dibinanya, meskipun ia berasal dari seorang atlet sekalipun. Oleh karena melatih tidak hanya mengandalkan keterampilan (skill) semata, melainkan juga harus didukung oleh pengetahuanpengetahuan yang relevan khususnya pengetahuan ilmu kepelatihan olahraga, bagaimana mungkin seorang pelatih mampu meningkatkan prestasi atlet jika pelatih tidak mampu merumuskan tujuan latihan, menentukan metode latihan dan memilih materi yang tepat, memahami prinsip-prinsip latihan dan yang paling mendasar adalah pemahaman tentang pengaturan beban latihan.

Pembinaan olahraga prestasi bertujuan untuk membina para anak-anak yang berprestasi didalam bidang olahraga yang sesuai dengan cabor masingmasing dan sesuai dengan tingkatannya. Dalam pencapaian hasil yang optimal, ada seorang pelatih yang benar-benar memahami materi dan program latihan apa yang akan diberikan pada atlet sudah dijelaskan di atas dan untuk meningkatkan kesegaran dan kebugaran jasmaninya, baik dari segi fisik maupun pikiran atlet karna seorang pelatih dituntut mengetahui apa hal yang berkaitan dengan kesehatan dan emosional atlet, karna apa yang ada pada atlet mempengaruhi dalam pencapaian prestasi pada atlet. Pentingnya menumbuhkan semangat dalam berlatih pada atlet adalah suatu tugas yang sangat penting bagi seorang pelatih, karena suport dari orang tua, keluarga dan pelatih adalah terpenting dalam 
mencapai kemenangan. Dengan demikian, proses latihan tidak lain adalah mempersiapkan para atlet akan kematangan kemampuan fisik, teknik, taktik dan mental dengan harapan berprestasi pada cabang yang digeluti.

Jika peran serta manusia yang melaksanakan olahraga itu sendiri baik orang tua, pelatih, atlet dan individunya secara jelas bahwa "manusia bukan hanya sekedar jasmani yang nampak pada umumnya secara kasat mata, namun juga memiliki spirit di dalam dirinya. Hal ini seringkali disebut dengan body, mind, dan soul"'(Okilanda 2018). Konteks ini mengarah pada peran serta pelatih yang bisa terus berfikir bagaimana terus berkembangnya atlit dan orang tua yang mendukung penuh sehingga prestasi bisa dicapai secara maksimal mundul dari jiwa sehingga terealisasi dengan raga yang bekerja secara maksimal.

Olahraga Beladiri Taekwondo sekarang dalam perkembanganya sangat populer di dunia tidak terkecuali di Indonesia. Taekwondo merupakan Olahraga Nasional Korea yang paling banyak dimainkan di dunia dan juga dipertandingkan di Olimpiade. Belakangan ini makin banyak digemari di kalangan pelajar dan mahasiswa di Indonesia.

Untuk itu seorang atlet taekwondo, di tuntut memiliki penguasaan teknikteknik dasar Taekwondo yang baik, sebab hal tersebut merupakan syarat utama untuk menjadi Taekwondoin yang bermutu dan memiliki keterampilan yang tinggi dalam berlatih Taekwondo(syafruddin 2013). Dalam mempelajari Taekwondo untuk menyerang dan bertahan terdapat lima komponen dasar-dasar Taekwondo" Adapun dasar-dasar Taekwondo tersebut yaitu :

1. Bagian tubuh yang menjadi sasaran

2. Bagian tubuh yang digunakan untuk menyerang atau bertahan

3. Sikap kuda-kuda

4. Teknik bertahan/menangkis

5. Teknik serangan, yang terdiri dari:
a. Pukulan (Jireugi)
b. Sabetan (Chigi)
c. Tusukan (Chireugi)
d. Tendangan (Chagi) 
Teknik dasar gerakan-gerakan pada Taekwondo lebih banyak diperankan dengan menggunakan kemampuan kaki untuk pertarungan atas "Standing Fighting”, tetapi bukan berarti tidak diajarkan gerakan-gerakan tangan. Gerakan tangan juga diajari tapi hanya sekitar kurang lebih 20 persen saja. Gerakangerakan tangan biasanya hanya di pakai untuk menangkis baik tangkisan atas maupun tangkisan bawah. Gerakan tangan ini juga dapat dipergunakan untuk melengkapi keindahan jurus-jurus (poomsae) di dalam Taekwondo.

Oleh karena itu, meningkatkan prestasi cabang olahraga pada umumnya dan khususnya pada cabang olahraga beladiri Taekwondo, aspek-aspek daya tahan dan kebugaran jasmani tersebut merupakan prioritas utama yang harus diperhatikan. Ketika akan melakukan kyorugi, para atlet di tuntut untuk dapat menguasai bukan hanya sekedar basic dasar maupun jurus dalam Taekwondo tetapi juga dalam segi daya tahan yang harus prima. Maka dari itu ketika melakukan materi dalam program latihan, pelatih memberikan materi atau program latihan guna meningkatkan kebugaran fisik daya tahan atlet. Karena atlet sering kali nafasnya tersengal-sengal karena kurangnya oksigen ketika atlet banyak melakukan gerakan karena body protector yang digunakan serta serangan dari lawan, maka dari itu pernafasan adalah hal yang paling penting agar dapat mengatur nafas dan mengatasi kelelahan ketika bertanding. Karena kebanyakan atlet di saat pertandingan adalah tidak mampu mengatasi kelelahan dan mengatur nafasnya sehingga, timbul rasa sesak dan tidak dapat menguasai diri ketika bertanding karena kurangnya daya tahan dan oksigen di dalam tubuh, jika seorang atlet mampu mengatur nafas dan daya tahan yang baik maka atlet tersebut dapat bertanding dengan baik. Karena ketika seseorang yang bugar sudah pasti sehat tetapi seseorang yang sehat belum tentu bugar, sehingga atlet di tuntut untuk menguatkan daya tahannya dan di perbanyakan latihan daya tahan.

Daya tahan paru jantung adalah kemampuan paru-paru jantung mensuplai oksigen untuk kerja otot dalam jangka waktu jadi seseorang yang mempunyai VO2max yang baik maka dalam penggunaan oksigen akan lebih maksimal sehingga daya tahan Kardiorespirasi menjadi lebih baik pula. Seseorang yang memiliki daya tahan yang baik dia tidak akan mudah merasa lelah atau capek 
setelah melakukan aktivitas keseharian, jika terjadi kelelahan dengan sedikit istirahat dapat mengembalikan kondisi tubuh seperti sediakala. Menurut (syafruddin 2011) "daya tahan adalah kemampuan organisme jantung, paru-paru, sistem pembulu darah, dan sistem peredaran darah untuk mengatasi kelelahan yang disebabkan oleh pembebanan latihan yang berlangsung relatif lama". Dalam Taekwondo sangat memerlukan daya tahan tubuh yang baik supaya dapat bermain dengan maksimal serta dapat berkonsentrasi penuh selama pertandingan berlangsung. Apabila seorang atlet Taekwondo memiliki teknik yang baik tetapi tidak memiliki daya tahan tubuh yang baik, maka kemampuan yang dimiliki tidak keluar dengan maksimal. Menurut (syafruddin 2011)"daya tahan dapat diartikan sebagai kemampuan seseorang mengatasi kelelahan akibat melakukan kerja fisik dan psikis dalam waktu lama". Hal ini dilihat ketika atlet bertanding di matras pertandingan, diawal pertandingan atlet dapat melakukan teknik yang baik, serta dapat melakukan tendangan-tendangan yang baik dalam pertandingan. Akan tetapi dalam menit akhir pertandingan atlet sering salah melakukan teknik, dikarenakan kurangnya pasukan oksigen didalam paru-paru karena daya tahan yang tidak baik.

Berdasarkan pengamatan yang dilakukan peneliti pada saat latihan di Club Taekwondo Suvivar 5 Palembang, banyaknya atlet yang belum mampu mengatur pernafasan mereka dalam melakukan latihan dengan intensitas tinggi dan disaat melakukan pertandingan sering kelelahan karena kurang daya tahan yang mereka miliki, ketika peneliti melakukan diskusi dengan pelatih yang mengajar di Suvivar 5 club Palembang, serta dari pertimbangan di atas serta belum adanya penelitian tentang kebugaran kardiorespirasi yanng di lakukan doejang Taekwondo Suvivar

5 club, maka peneliti tertarik untuk melakukan penelitian tentang “ Pengaruh latihan jogging terhadap daya tahan kardiorespirasi pada atlet Taekwondo Suvivar 5 club Palembang.

\section{METODE}

Metode menggunakan eksperimen, dalam artikel ini penulis menggunakan eksperimen semu. Eksperimen semu adalah eksperimen yang memiliki perlakuan 
(treatments), pengukuran-pengukuran dampak (outcome measure), dan unit-unit eksperiment namun tidak menggunakan penempatan secara acak.

Populasi adalah wilayah generalisasi yang terdiri atas obyek/subyek yang mempunyai kualitas dan karakteristik tertentu yang ditetapkan oleh peneliti untuk di pelajari dan di tarik kesimpulannya, menurut (Sugiyono 2008). Dalam penelitian ini populasi keseluruhan yaitu ada 30 siswa di Taekwondo Suvivar 5 club Palembang di antara nya 15 kelas reguler (anak-anak) dan 15 kelas atlet (dewasa)

Sampel adalah sebagian dari populasi yang diteliti. Berdasarkan pendapat para ahli diatas sampel ini menggunakan teknik purposive sampling di karenakan atlet yang di teliti sudah paham apa yang akan di teliti oleh peneliti, dan peneliti mengambil 15 atlet dari 30 orang, di karenakan memudahkan peneliti menjelajahi obyek/situasi sosial yang di teliti menurut (Sugiyono 2008), Atlet putra tingkat kekuatan fisik nya lebih kuat serta secara biologi dilihat dari kerangka otot, otot atlet putra lebih besar dari pada atlet anak-anak dan atlet putri, peneliti mengambil sampel dari populasi yaitu berdasarkan tujuan peneliti adalah untuk mengetahui pengaruh latihan jogging terhadap daya tahan kardiorespirasi, jumlah keseluruhan sampel adalah :

Tabel.1 Jumlah keseluruhan atlet putra yang diteliti

\begin{tabular}{cccc} 
Umur & Jenis kelamin & Jumlah & Kelas \\
$\mathbf{2 0 - 2 9}$ & Laki-laki & $\mathbf{1 5}$ Orang & Dewasa \\
\hline
\end{tabular}

Sumber : M. Eko akhta Suvivar(ketua club Suvivar 5)

Rancangan yang di gunakan dalam penelitian ini adalah “one group pre test dan post tes desaign” secara skematis di gambarkan seperti ini.

Tabel. 2 one group pre test dan post tes desaign

\begin{tabular}{l} 
Pre test \\
\multicolumn{1}{c}{$\mathbf{O}_{1}$} \\
\hline : \\
wal ( pretest) sebelum perlakuan diberikan \\
khir ( Posttest) setelah perlakuan diberikan
\end{tabular}


$\mathrm{X}$ : Perlakuan terhadap kelompok eksperimen yaitu dengan menerapkan latihan jogging kepada atlet.

\section{HASIL DAN PEMBAHASAN}

Subjek dalam penelitian ini, yaitu atlet Suvivar 5 Club Palembang sebanyak 15 atlet. Beep test dilakukan sebanyak dua kali, yaitu pretest dan posttest. Pretest bertujuan untuk mencari reliabilitas, merangking, membagi dua kelompok, dan membandingkan dengan hasil posttest. Beep test diberikan sebelum atlet diberikan perlakuan (treatment) (posttest) untuk mengetahui daya tahan yang dia miliki sebelum melakukant latihan dan akan di bandingkan dengan test hasil akhir (pre test) setelah diberikan perlakuan agar mengetahui adakah pengaruh atau tidak dalam penelitian ini. Hasil penelitian tersebut dideskripsikan sebagai berikut :

Hasil pretest (tes awal), Eksperimen Atlet putra Pengaruh latihan Jogging terhadap daya tahan kardiorespirasipada Atlet Taekwondo Suvivar 5 Club Taekwondo

1). Distribusi frekuensi bergolong tes awal langkah-langkah sebagai berikut.

a. Rentang, data terbesar - data terkecil, $10-6=4$

b. Panjang kelas, $1+3,3 \log \mathrm{n}, 1+3,3 \times \log 15=4.96$ (5)

c. Banyak kelas, rentang : panjang kelas, $4: 5=0.8$

Tabel .3 Distribusi Frekuensi Tes Awal

$\begin{array}{llll}\text { No } & \text { Interval Kelas } & \begin{array}{l}\text { Frekuensi } \\ \text { Absolute (fa) }\end{array} & \begin{array}{l}\text { Frekuensi } \\ \text { Relatif (fr) }\end{array}\end{array}$

\begin{tabular}{llll}
\hline 1. & $6-6.8$ & 2 & $13 \%$ \\
\hline 2. & $6.9-7.7$ & 2 & $13 \%$ \\
\hline 3. & $7.8-8.6$ & 3 & $20 \%$ \\
\hline 4. & $8.7-9.5$ & 4 & $27 \%$ \\
\hline 5. & $9.6-10.4$ & 4 & $27 \%$ \\
\hline Jumlah & 15 & $100 \%$ \\
\hline $\begin{array}{l}\text { Mean }=8.4 \\
\text { Median }=9\end{array}$ & &
\end{tabular}


Standar Deviasi $=1.4$

Varian $=1.97$

Berdasarkan tabel.7 diatas, interval kelas 6-8,8 sebanyak 2 orang (13\%), 6,9-7,7 sebanyak 2 orang (13\%), 7,8-8,6 sebanyak 3 orang (20\%) , 8,7-9,5 sebanyak 4 orang $(27 \%)$, 9,6-10,4 sebanyak 4 orang (27\%), untuk Mean 8,9, median 9, dengan standar deviasi 1,4 dan varian 1,9 untuk lebih jelas dapat dilihat histogram dibawah ini.

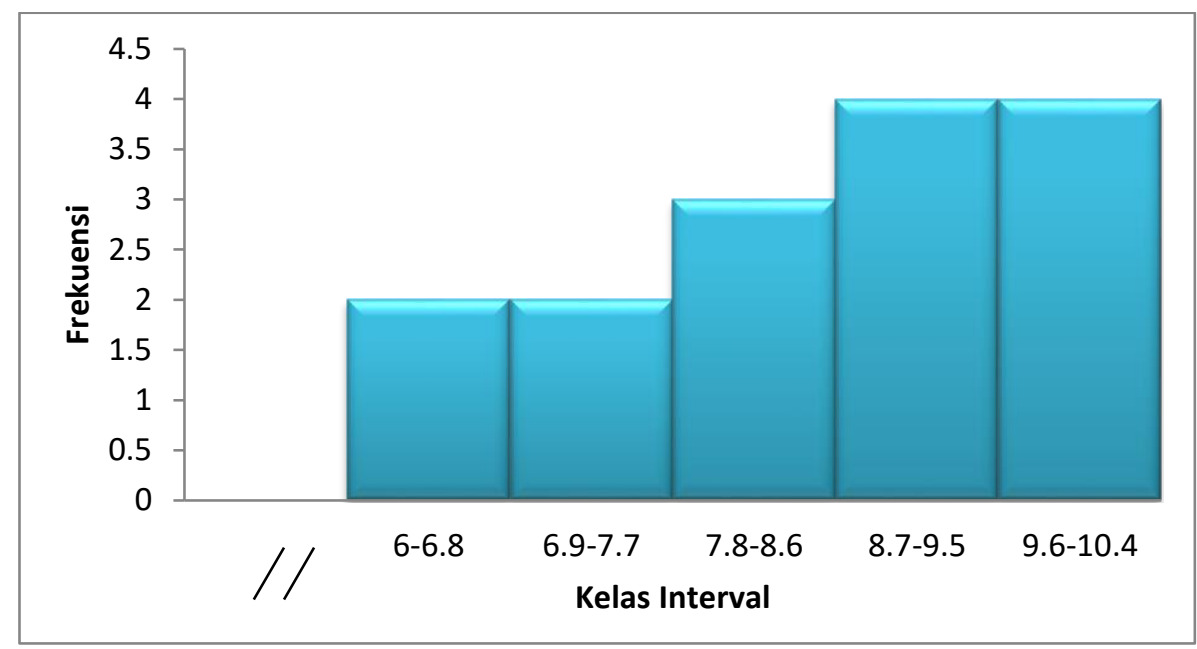

Gambar.1 Histogram Tes Awal

Hasil postest (tes akhir), Eksperimen Atlet putra Pengaruh latihan Jogging terhadap daya tahan kardiorespirasipada Atlet Taekwondo Suvivar 5 Club Taekwondo

1). Distribusi frekuensi bergolong tes akhir langkah-langkah sebagai berikut.

a. Rentang, data terbesar - data terkecil, $12-7=5$

b. Panjang kelas, $1+3,3 \log \mathrm{n}, 1+3,3 \times \log 10=4.96(5)$

c. Banyak kelas, rentang : panjang kelas, $5: 4.3=1.16$ 
Tabel .4 Distribusi Frekuensi Tes Akhir

\begin{tabular}{llll}
\hline No & Interval Kelas & $\begin{array}{l}\text { Frekuensi } \\
\text { Absolute (fa) }\end{array}$ & $\begin{array}{l}\text { Frekuensi } \\
\text { Relatif (fr) }\end{array}$ \\
\hline 1. & $7-8.16$ & 4 & $27 \%$ \\
\hline 2. & $8.17-9.33$ & 3 & $20 \%$ \\
\hline 3. & $9.34-10.50$ & 3 & $20 \%$ \\
\hline 4. & $10.51-11.67$ & 2 & $13 \%$ \\
\hline 5. & $11.68-12.84$ & 3 & $20 \%$ \\
\hline Jumlah & & 15 & \\
\hline $\begin{array}{l}\text { Mean }=53.75 \\
\text { Median }=53.13\end{array}$ & & \\
Standar Deviasi $=10.70$ & & \\
Varian $=114$ & & \\
\hline
\end{tabular}

Berdasarkan tabel.8 diatas , interval kelas 7-8,16 sebanyak 4 orang (27\%), 8,17-9,33 sebanyak 3 orang (20\%), 9,34-10,50 sebanyak 3 orang $(20 \%)$, 10,5111,67 sebanyak 2 orang (13\%) , 11,68-12,84 sebanyak 3 orang (20\%), untuk Mean 53,75, median 53,13, dengan standar deviasi 10,70 dan varian 114 untuk lebih jelas dapat dilihat histogram dibawah ini.

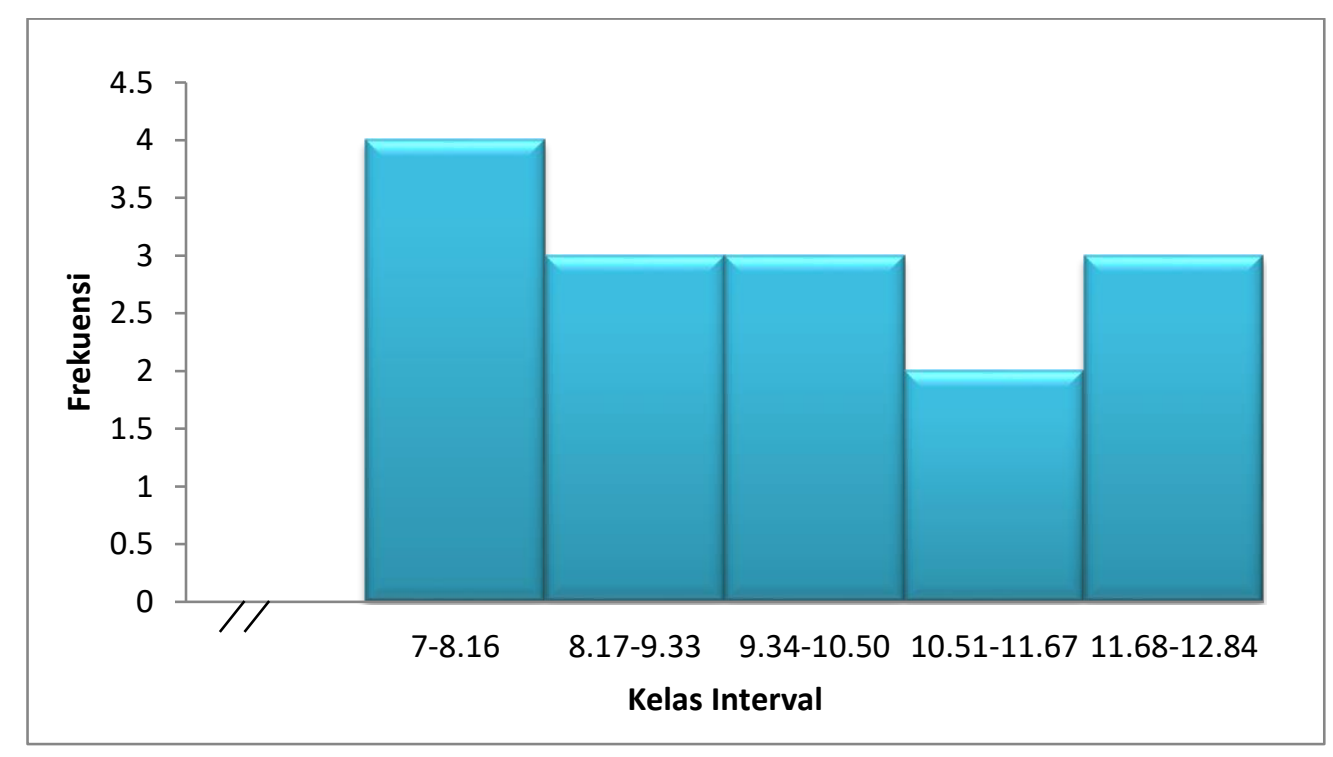

Gambar.2 Histogram Tes Akhir 


\section{Deskripsi dan Analisis Data}

Analisis data digunakan untuk menjawab hipotesis yang diajukan. Sebelum analisis data dilakukan, maka perlu dilakukan uji prasayarat analisis yaitu dengan uji normalitas, dan uji homogenitas. Hasil uji prasyarat dan uji hipotesis dapat dilihat sebagai berikut:

\section{Uji Prasyarat}

\section{a. Uji Normalitas}

Uji kenormalan dengan uji Liliefors menggunakan konsep statistika non parametrik. Misalkan kita mempunyai sampel acak dengan hasil pengamatan $\mathrm{X}_{1}, \mathrm{X}_{2},{ }_{,},,{ }_{,} \mathrm{Xn}$.Berdasarkan sampel ini akan diuji hipotesis nihil $\left(\mathrm{H}_{0}\right)$ bahwa sampe tersebut berasal dari populasi berdistribusi normal melawan hipotesis alternatif (H1) bahwa populasi yang berdistribusi tidak normal. Untuk pengujian hipotesis nihil tersebut kita tempuh dengan prosedur sebagai berikut :

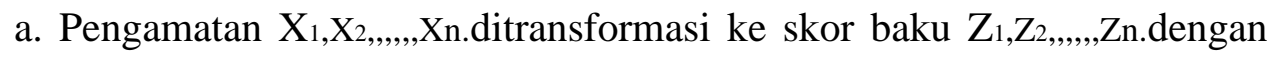
menggunakan rumus $Z=\frac{x 1-x}{s}$, dimana $\mathrm{x}$ dan s masing-masing merupakan rata-rata dan standar deviasi sampel.

b. Untuk tiap bilangan baku ini dan menggunakan daftar distribusi normal baku, kemudian dihitung peluang $\mathrm{F}(\mathrm{zi})=\mathrm{P}(\mathrm{z}<\mathrm{zi})$.

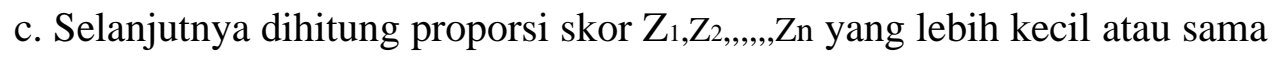
dengan zi. Jika proporsi ini dinyatakan oleh $\mathrm{S}(\mathrm{zi})$, maka $\mathrm{S}(\mathrm{zi})=$ $\frac{\text { banyaknya } z 1, z 2, \ldots, z n \leq z 1}{n}$.

d. Hitungkah selisih F(zi)-S(zi) kemudian tentukan harga mutlaknya.

e. Ambil harga yang paling besar diantara harga-harga mutlak selisih tersebut sebutlah harga terbesar ini Lo.

Maka uji normalitas dimaksudkan untuk mengetahui apakah variabelvariabel dalam penelitian mempunyai sebaran distribusi normal atau tidak. Penghitungan uji normalitas ini menggunakan rumus uji-T yang menggunakan komputer manual hasilnya sebagai berikut. 
Tabel.5 Rangkuman Uji Normalitas dengan Uji Liliefors

\begin{tabular}{lllll}
\hline Data & $\mathbf{N}$ & $\mathbf{L} \mathbf{H}$ & $\mathbf{L} \mathbf{t}$ & Keterangan \\
\hline Tes awal & 10 & 0.1321 & 0.2200 & Normal \\
\hline Tes akhir & 10 & 0.1177 & 0.2200 & Normal \\
\hline
\end{tabular}

Dari hasil tabel di atas dapat dilihat bahwa data dari semua variabel memiliki nilai terbesar pada tes awal (pretest) 0.132 dan 0.1177 nilai terbesar tes akhir (posttest) dengan T tabel 0,2200. Maka semua variabel berdistribusi normal. Karena semua data berdistribusi normal maka analisis dapat dilanjutkan.

$$
\begin{aligned}
& t=\frac{\bar{X}_{1}-\bar{X}_{2}}{\sqrt{\frac{\sum D^{2} \frac{\left(\sum D\right)^{2}}{n}}{n(n-1)}}} \\
& t=\frac{8.4-9.68}{\sqrt{\frac{27-\frac{(-19)^{2}}{15}}{15(15-1)}}} \\
& t=\frac{1.28}{\sqrt{\frac{3}{210}}} \\
& t=11
\end{aligned}
$$

Berdasarkan hasil uji hipotesis di atas maka diperoleh nilai $t_{\text {hitung }}$ adalah 11 untuk kesalahan 5\% (taraf kepercayaan 95\% =0,05) derajat kebebasan $(\mathrm{dk})=$ $\mathrm{n}-1=15-1=14$, adalah $\mathrm{t}_{\text {tabel }}=1.761$ lebih besar $\left(\mathrm{t}_{\text {hitung }} \geq \mathrm{t}_{\text {tabel }}\right)$ atau $11 \geq$ 1.761 maka demikian hasil analisis di atas bahwa Ho ditolak Ha diterima kebenarannya, yaitu pengaruh latihan joging terhadap daya tahan kardiorespirasi pada atlet taekwondo Suvivar 5 Club Palembang.

\section{KESIMPULAN}

Berdasarkan hasil analisis data dan pembahasan dalam skripsi ini, maka dapat disimpulkan bahwa latihan jogging memberikan pengaruh yang signifikan terhadap daya tahan kardiorespirasi pada atlet takwondo suvivar 5 club 
palembang. Hal ini dapat dilihat dari hasil uji hipotesis maka $t_{\text {hitung }}$ adalah 11 untuk kesalahan 5\% (taraf kepercayaan 95\% =0,05) derajat kebebasan $(\mathrm{dk})=\mathrm{n}-$ $1=15-1=14$, adalah $t_{\text {tabel }}=1.761$ lebih besar $\left(t_{\text {hitung }} \geq t_{\text {tabel }}\right)$ atau $11 \geq 1.761$. Dengan tingkat signifikan $\alpha=0,05$ ini berarti bahwa ada pengaruh latihan jogging memberikan pengaruh yang signifikan terhadap daya tahan kardiorespirasi pada atlet takwondo suvivar 5 club palembang. Dengan demikian hipotesis penelitian terbukti bahwa latihan jogging memberikan pengaruh yang signifikan terhadap daya tahan kardiorespirasi pada atlet takwondo suvivar 5 club palembang.

\section{DAFTAR PUSTAKA}

Okilanda, Ardo. 2018. "Revitalisasi Masyarakat Urban/Perkotaan Melalui Olahraga Petanque." Halaman Olahraga Nusantara (Jurnal Ilmu Keolahragaan) $1(1)$. http://garuda.ristekbrin.go.id/documents/detail/1459414

Sugiyono,. 2008. "Metode Kuantitatif Dan Kualitatif.” Bandung . Syafruddin. 2011. "ILmu Kepelatihan Olahraga.” UNP Press.

Syafruddin. 2013. "Ilmu Kepelatihan Olahraga Teori Dan Aplikasinya Dalam Pembinaan Olahraga.” UNP Press. 